\title{
Avaliação da alfabetização: Provinha Brasil
}

\author{
Cláudia Maria Mendes Gontijo
}

Universidade Federal do Espirito Santo

\section{Resumo}

Este texto é parte dos resultados de uma pesquisa documental mais ampla, cuja finalidade foi analisar os programas voltados para a alfabetização infantil implementados pelo Ministério da Educação a partir do ano de 2003. Busca compreender as origens do Programa de Avaliação da Alfabetização e as mudanças que ocorreram durante seu desenvolvimento; além disso, fundamentado no exame da Matriz de Referência para Avaliação da Alfabetização e do Letramento Inicial e dos documentos que compõem o kit da Provinha Brasil, visa a entender as concepções de alfabetização, de letramento inicial, de língua/linguagem e de leitura que sustentam o modelo de avaliação adotado pelo Ministério da Educação. Conclui que o programa tem origem nas definições de organismos mundiais para a década da alfabetização (2003-2012). 0 modelo autônomo de alfabetização ancora o Programa de Avaliação e, por isso, a ênfase é depositada no aprendizado das unidades abstratas da língua. A leitura, dimensão ligada ao letramento inicial, é compreendida como processo de decodificação e de identificação de ideias expressas de forma explícita em pequenos textos. Considerando os aspectos analisados, o artigo avalia que a concepção de língua/linguagem como estrutura sustenta a elaboração da Matriz de Referência e a construção dos itens da prova. Questiona, finalmente, de que modo a Provinha Brasil, pensada como instrumento pedagógico, poderá contribuir para a formação de leitores e escritores.

\section{Palavras-chave}

Avaliação - Alfabetização - Leitura - Escrita.

Correspondência:

Cláudia Maria Mendes Gontijo

clammg@terra.com.br 


\title{
The assessment of literacy: the Provinha Brasil
}

Cláudia Maria Mendes Gontijo

Universidade Federal do Espírito Santo

\begin{abstract}
The present text is part of the results of a wider documental study whose objective was to analyze the programs focused on child literacy implemented by the Ministry for Education since 2003. It seeks to understand the origins of the Program for Literacy Assessment and the changes that happened during its development; also, based on the exam of the Reference Matrices for the Assessment of Full and Initial Literacy and of the documents that comprise the kit of the Provinha Brasil, it aims at understanding the conceptions of full and initial literacy, of idiom/language and of reading that give support to the assessment model adopted by the Ministry for Education. It concludes that the program has its origins in the definitions made by world organizations for the literacy decade (2003-2012). The autonomous model of literacy is the ground of the Assessment Program and, because of that, the emphasis lies on the learning of the abstract units of language. Reading, a dimension associated to initial literacy, is understood as the process of decoding and identifying ideas expressed in explicit form in short texts. Considering the aspect analyzed, the article proposes that the conception of idiom/language as a structure sustains the creation of the Reference Matrices and the construction of the topics of the exam. Finally, it questions in what way the Provinha Brasil, thought of as a pedagogical instrument, may be able to contribute to the formation of readers and writers.
\end{abstract}

\section{Keywords}

Assessment - Literacy - Reading - Writing. 
Este artigo é o desdobramento de uma pesquisa documental mais ampla cujo objetivo foi analisar as políticas de alfabetização infantil implementadas pelo Ministério da Educação (MEC) a partir de 2003. Assim, tem por finalidade examinar o Programa de Avaliação da Alfabetização, tomando como objeto de análise os documentos que constam do kit da Provinha Brasil, em todos os anos de sua aplicação, disponíveis na página eletrônica do MEC, bem como a Matriz de Referência para Avaliação da Alfabetização e do Letramento Inicial.

Sabemos que a Provinha Brasil, instrumento instituído pela Portaria Normativa $\mathrm{n}^{0} 10$, de 26 de abril de 2007, foi aplicada pela primeira vez em abril de 2008. Receberam o material impresso para participar dessa primeira edição 3.133 municípios e 22 unidades federativas. A partir do segundo semestre de 2008, todas as secretarias de educação do país passaram a receber o material impresso para aplicação às crianças em fase inicial de escolarização. Os objetivos do programa são

avaliar o nível de alfabetização dos alunos/ turma nos anos iniciais do ensino fundamental; diagnosticar possíveis insuficiências das habilidades de leitura e escrita. ${ }^{1}$

Nesse sentido, segundo informações contidas na página eletrônica do MEC, a Provinha Brasil é um instrumento pedagógico que fornece subsídios para o desenvolvimento de práticas alfabetizadoras, devendo ser aplicada às crianças que estão matriculadas no $2^{\circ}$ ano do ensino fundamental, em duas etapas, a cada ano.

No ano de 2010, o programa contou com a participação de várias instituições, mas, a partir de 2011, os documentos que compõem o kit da Provinha passaram a ser elaborados pelo Instituto Nacional de Estudos e Pesquisas Educacionais Anísio Teixeira (Inep), Diretoria de Avaliação da Educação Básica (Daeb) e Coordenação-Geral do Sistema Nacional de Avaliação da Educação

1- Disponível em: <http://provinhabrasil.inep.gov.br/>. Acesso em: 29 mar. 2012.
Básica, com a colaboração do Ministério da Educação, Secretaria de Educação Básica (SEB/ MEC), Centro de Formação Continuada de Professores da Universidade de Brasília (Ceform) e Centro de Estudos em Educação e Linguagem da Universidade Federal de Pernambuco (Ceel).

Atualmente, há poucos trabalhos que se detêm a analisar os impactos da avaliação da alfabetização nas práticas escolares nos dois primeiros anos do ensino fundamental e, também, que analisam os documentos que compõem o kit da Provinha Brasil. No Banco de Teses e Dissertações da Coordenação de Aperfeiçoamento de Pessoal de Nível Superior (Capes), encontramos apenas uma tese (DANTAS, 2009) que trata da política de avaliação da alfabetização em larga escala implementada no Estado da Bahia. Artigos publicados em periódicos e em anais de congresso têm analisado experiências de Estados brasileiros que implementaram sistemas próprios de avaliação da alfabetização (MARQUES; AGUIAR; CAMPOS, 2009; CARVALHO; MACEDO, 2010; ROCHA; MARTINS, 2010).

0 artigo de João Batista de Araújo e Oliveira (2005) critica as propostas de avaliação da alfabetização por não considerarem princípios psicométricos elementares e, também, propõe um modelo de avaliação baseado em experiências estrangeiras. Por outro lado, Maria Teresa Esteban (2009) critica a avaliação por seu caráter eminentemente classificatório e por não levar em conta a realidade sociocultural dos educandos. Neste artigo, buscamos compreender as origens do Programa de Avaliação da Alfabetização, as mudanças que nele ocorreram durante o período de implementação (de 2008 a 2011) e analisamos a Matriz de Referência para Avaliação da Alfabetização e do Letramento Inicial, bem como documentos que compõem o kit da Provinha, no intuito de entender as concepções de alfabetização, de letramento inicial, de língua/linguagem e de leitura que sustentam o modelo de avaliação adotado pelo MEC e disseminado nas escolas.

Como escrito no documento Reflexões sobre a prática (BRASIL, 2011b), a Provinha é 
de grande serventia para cada uma das instâncias responsáveis pela alfabetização (gestores, escola, professores etc.). No caso dos gestores, ela poderá ajudá-los a

fazer escolhas bem fundamentadas em sua gestão, reunindo elementos para o planejamento curricular e para subsidiar a formação continuada dos professores alfabetizadores, a fim de melhorar a qualidade do ensino em sua rede. (p. 6)

Assim, a Provinha Brasil visa a contribuir para a melhoria da qualidade do ensino nas redes municipais e estaduais.

No documento intitulado Passo a passo (BRASIL, 2010b), que

traz as principais informações sobre o contexto de criação da Provinha Brasil: seus objetivos, os pressupostos teóricos que a fundamentam, a metodologia, as possibilidades de interpretação e uso dos seus resultados e, ainda, as perspectivas para os próximos ciclos (p. 3),

menciona-se que a Provinha é um instrumento que visa, ainda, a oferecer aos professores e gestores das escolas públicas "um diagnóstico do nível de alfabetização dos alunos, ainda no início do processo de aprendizagem" (p. 6). Conforme escrito no mesmo documento, essa avaliação diferencia-se das demais que são elaboradas pelo Inep, porque se constitui em um instrumento pedagógico sem finalidades classificatórias. Sendo assim, não há previsão de utilização dos resultados para composição do Índice de Desenvolvimento da Educação Básica (Ideb).

\section{A criação da Provinha Brasil}

A decisão de avaliar a alfabetização no Brasil e, principalmente, a inclusão do programa de avaliação no Plano de Desenvolvimento Educacional (PDE) podem ser interpretadas de duas maneiras. Em primeiro lugar, o Fórum
Mundial de Educação, realizado em Dakar, Senegal, no período de 26 a 28 de abril de 2000, estabeleceu metas que visam à melhoria da educação no mundo. A alfabetização é o elemento que articula essas metas. A última delas refere-se à necessidade de garantir a excelência da educação, o que será assegurado por meio da mensuração de resultados, principalmente em relação à alfabetização, ao cálculo e às habilidades essenciais para a vida. Assim, o PDE, ao integrar dentre seus programas a avaliação da alfabetização, responde a essa última meta.

Em segundo lugar, também é necessário lembrar que o relatório elaborado pelo grupo de trabalho (GT) constituído pela Comissão de Educação e Cultura da Câmara dos Deputados, em 2003, aponta a necessidade, a partir dos modelos internacionais adotados, principalmente, nos Estados Unidos, na França e na Inglaterra, de criação de um sistema para avaliar a alfabetização. 0 GT compara a experiência nacional de avaliação com as internacionais, enfatizando as seguintes diferenças:

Na maioria dos países, existem políticas, mecanismos e instrumentos específicos para avaliação da alfabetização - normalmente feita ao final do primeiro ou segundo ano escolar, conforme o programa de ensino.

Países como Estados Unidos e Inglaterra, de modo particular, têm-se baseado nos resultados das avaliações - e nas medidas corretivas nelas assentadas para lograr importantes melhorias no desempenho de seus alunos na alfabetização. (BRASIL, 2007, p. 156-157)

Assim, a implementação da Provinha Brasil pode ser entendida também no contexto das proposições do relatório do GT (BRASIL, 2007), que apresenta, como orientação para o MEC, a implementação de avaliação sistemática e permanente dos resultados da alfabetização. Porém, o programa implantado não tem as características pensadas pelo GT, pois a Provinha é aplicada duas vezes por ano, e não apenas no final. Conforme apontado, ela também não 
servirá para compor os resultados do Ideb, mas deve auxiliar na gestão da alfabetização no interior das escolas, nos municípios e nos Estados.

No documento Passo a passo (BRASIL, 2008b), a necessidade de avaliação da alfabetização é explicada a partir do baixo desempenho em leitura dos estudantes brasileiros, atestado por outras avaliações nacionais. Nesse sentido, tal como apresentado, são razões ligadas à melhoria da qualidade da educação que justificam a implementação da avaliação da alfabetização. Esse seria um meio de detectar problemas no processo e evitar futuros fracassos. Gladys Rocha e Raquel Fontes Martins (2010) explicam a necessidade de implementação do programa de avaliação nacional da alfabetização:

(1) os resultados do SAEB, que apontam baixos indices de habilidades dos examinandos em leitura na $4^{\mathrm{a}} \mathrm{e} 8^{\mathrm{a}}$ séries;

(2) a meta estabelecida pelo governo federal de toda criança estar lendo e escrevendo aos oito anos de idade;

(3) a expectativa, social e historicamente constituída, em torno do domínio da leitura e da escrita como uma das funções precípuas da escola - expectativa não concretizada para grande parte dos alunos das escolas públicas. (s. p.)

A complicada relação entre alfabetização e desenvolvimento econômico, social e individual tem balizado o empenho dos organismos internacionais e dos governos nacionais em envidar esforços para a melhoria da alfabetização. Porém, na perspectiva dos organismos e governos, o que se observou, no início do século XXI, foi a incapacidade das escolas em gerir a alfabetização de modo que se obtenha dela os resultados esperados, ou seja, a formação de indivíduos capazes de continuar a aprender. Por isso mesmo, é preciso intervir diretamente nesse processo por meio do controle de seus resultados. Um sistema de avaliação é o melhor mecanismo para atender às finalidades de controle, porque, mesmo que os resultados da Provinha Brasil não estejam sendo utilizados pelo MEC para compor os índices nacionais de desenvolvimento da educação, a existência da avaliação produz efeitos singulares nos sujeitos envolvidos. Nesse sentido, a Matriz de Referência para Avaliação da Alfabetização e do Letramento Inicial tem contribuído para a organização do ensino nas escolas. Além disso, conforme relatos de professores e pedagogos, em muitas escolas, estão acontecendo os chamados vestibulinhos, ou seja, as crianças estão sendo treinadas previamente para fazer a prova. No vestibulinho, as escolas utilizam as versões das provas já aplicadas. Essa é uma estratégia que poderá ser eficaz, porque, como veremos posteriormente, os itens que compõem as diversas versões aplicadas até o segundo semestre de 2011 são muito semelhantes.

\section{Mudanças na Provinha Brasil}

A Provinha Brasil, desde sua implementação em 2008, passou por mudanças que serão destacadas neste tópico. De modo geral, exceto por uma delas, podemos concluir que essas mudanças foram basicamente relacionadas com aspectos quantitativos, pois houve uma diminuição no número de instituições envolvidas na elaboração da prova (conforme mencionado na introdução do presente artigo), dos eixos e dos descritores que organizam a Matriz de Referência, dos itens do teste e dos documentos que compõem o kit da prova.

Apesar da adoção de instrumentais que permitem a aferição dos resultados de testes, têm sido percebidos limites quando se trata, por exemplo, de avaliar o eixo escrita e de construir itens com ele relacionados. Nesse sentido, a Matriz de Referência para Avaliação da Alfabetização e do Letramento Inicial (2008) propunha três eixos: apropriação do sistema de escrita, leitura e escrita. Entretanto, no ano de 2009, esse último eixo, essencial no processo de alfabetização, foi retirado do documento. 0 Quadro 1 apresenta os eixos, para os anos de 2008, 2009, 2010 e 2011, contidos na Matriz de Referência. 
Quadro 1 - Eixos contemplados na Matriz de Referência para Avaliação da Alfabetização e do Letramento Inicial no período de 2008 a 2011

\begin{tabular}{|c|c|c|c|}
\hline 2008 & 2009 & 2010 & 2011 \\
\hline $\begin{array}{l}\text { Apropriação do sistema } \\
\text { de escrita }\end{array}$ & $\begin{array}{l}\text { Apropriação do sistema de } \\
\text { escrita: habilidades relacionadas } \\
\text { com a identificação e o } \\
\text { reconhecimento de princípios do } \\
\text { sistema de escrita }\end{array}$ & $\begin{array}{l}\text { Apropriação do sistema de } \\
\text { escrita: habilidades relacionadas } \\
\text { com a identificação e } 0 \\
\text { reconhecimento de princípios do } \\
\text { sistema de escrita }\end{array}$ & $\begin{array}{l}\text { Apropriação do sistema de escrita: } \\
\text { habilidades relacionadas com a } \\
\text { identificação e o reconhecimento } \\
\text { de princípios do sistema de escrita }\end{array}$ \\
\hline Leitura & Leitura & Leitura & Leitura \\
\hline Escrita & & & 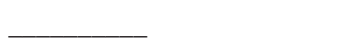 \\
\hline
\end{tabular}

Fonte: Dados da pesquisa.

Como mostra o Quadro 1, os eixos foram alterados uma vez, em 2009, e permaneceram os mesmos nos anos de 2010 e 2011. A mudança consistiu na exclusão do eixo escrita, restando apenas os eixos apropriação do sistema de escrita e leitura, ou seja, elementos ligados à técnica da escrita e da leitura. 0 eixo compreensão e valorização da cultura escrita, que diz respeito

aos aspectos que permeiam o processo de alfabetização e letramento, permitindo o conhecimento e a valorização dos modos de produção e circulação da escrita na sociedade, considerando os usos formalizados no ambiente escolar e os de ocorrência mais espontânea no quotidiano (BRASIL, 2010b, p. 11),

não constitui a matriz sob a forma de descritores, capacidades ou habilidades.

A Matriz de Referência congrega os descritores/habilidades que serão avaliados na Provinha. 0 quadro a seguir apresenta os/as descritores/habilidades ligados/as ao eixo apropriação do sistema de escrita:

Quadro 2 - Descritores que compõem o eixo apropriação do sistema de escrita no período de 2008 a 2011

\begin{tabular}{|c|c|c|c|c|}
\hline Eixo & 2008 & 2009 & 2010 & 2011 \\
\hline \multirow[t]{6}{*}{$\begin{array}{l}\text { Apropriação do } \\
\text { sistema de escrita }\end{array}$} & $\begin{array}{l}\text { D1. Diferenciar letras de outros sinais } \\
\text { gráficos, como os números, sinais de } \\
\text { pontuação ou de outros sistemas de } \\
\text { representação. }\end{array}$ & D1: Reconhecer letras. & D1: Reconhecer letras. & D1: Reconhecer letras. \\
\hline & D2. Identificar letras do alfabeto. & $\begin{array}{l}\text { D2: Reconhecer } \\
\text { sílabas. }\end{array}$ & $\begin{array}{l}\text { D2: Reconhecer } \\
\text { sílabas. }\end{array}$ & $\begin{array}{l}\text { D2: Reconhecer } \\
\text { sillabas. }\end{array}$ \\
\hline & $\begin{array}{l}\text { D3. Reconhecer palavras como } \\
\text { unidade gráfica. }\end{array}$ & $\begin{array}{l}\text { D3: Estabelecer } \\
\text { relação entre } \\
\text { unidades sonoras e } \\
\text { suas representações } \\
\text { gráficas. }\end{array}$ & $\begin{array}{l}\text { D3: Estabelecer } \\
\text { relação entre } \\
\text { unidades sonoras e } \\
\text { suas representações } \\
\text { gráficas. }\end{array}$ & $\begin{array}{l}\text { D3: Estabelecer } \\
\text { relação entre } \\
\text { unidades sonoras e } \\
\text { suas representações } \\
\text { gráficas. }\end{array}$ \\
\hline & $\begin{array}{l}\text { D4. Distinguir diferentes tipos de } \\
\text { letras. }\end{array}$ & & & \\
\hline & $\begin{array}{l}\text { D5. Identificar sílabas de palavras } \\
\text { ouvidas e/ou lidas. }\end{array}$ & & & \\
\hline & $\begin{array}{l}\text { D6. Identificar relações fonema/ } \\
\text { grafema (som/letra). }\end{array}$ & & & \\
\hline
\end{tabular}

Fonte: Dados da pesquisa. 
Assim, a partir do ano de 2009, os organizadores da Matriz passaram a privilegiar apenas três descritores no primeiro eixo, sem que isso implicasse a retirada de todo o conjunto de descritores avaliados nos testes aplicados em 2008, pois alguns deles passaram a ser definidos em termos de capacidades associadas a descritores/habilidades mantidos/mantidas. Dessa maneira, os organizadores da Matriz de Referência (2009), ao detalharem o primeiro descritor/habilidade (reconhecer letras), definem que ele está relacionado com as capacidades de "diferenciar letras de outros sinais gráficos, identificar pelo nome as letras do alfabeto ou reconhecer os diferentes tipos de grafia das letras" (BRASIL, 2009, p. 14). 0 segundo descritor/ habilidade está associado à capacidade de identificar "número de sílabas que formam uma palavra por contagem ou comparação das sílabas de palavras dadas por imagens" (p. 14). Finalmente, o terceiro está relacionado com a capacidade de

identificar em palavras a representação de unidades sonoras como: vogais nasalizadas; letras que possuem correspondência sonora única (ex.: $p, b, t, d, f)$; letras com mais de uma correspondência sonora (ex.: c e g); e sílabas. (BRASIL, 2009, p. 14)

Desse modo, podemos observar que, em se tratando da apropriação do sistema de escrita, há uma redução dos descritores/habilidades com permanência daqueles que induzem a práticas de ensino que privilegiam as unidades abstratas da língua (letras e sílabas). Esse eixo está relacionado com a alfabetização. 0 eixo leitura, por sua vez, está associado ao letramento inicial, já que o teste pretende avaliar esses dois processos.

Com relação ao eixo escrita, suprimido da Matriz adotada no período de 2009 a 2011, o documento Passo a passo (BRASIL, 2008b) esclarece que a escrita é entendida como produção que vai além da codificação e se traduz em atividade social, cujos conteúdo e forma se relacionam a objetivos específicos, a leitores determinados, a um contexto previamente estabelecido. (p. 10)

Dessa forma, para que a criança se torne um escritor competente, afirma-se que

é necessário desenvolver desde habilidades no nível da codificação de palavras formadas por sílabas simples (consoante-vogal) e complexas (consoante-vogal-consoante, ou consoante-consoante-vogal, por exemplo), até escrever bilhetes, cartas, histórias entre outros gêneros. (p. 16)

0 texto acrescenta, ainda, que, na escrita de textos, as crianças precisam

saber dispor, ordenar e organizar as idéias numa seqüência que atenda à lógica e a apresentação gráfica convencionada para o gênero; escrever usando o princípio alfabético e as regras ortográficas; saber planejar o texto em função dos objetivos e leitores; usar a variedade lingüística adequada à situação; usar adequadamente o vocabulário e as regras gramaticais; utilizar recursos expressivos adequados à situação comunicativa; revisar e reelaborar o próprio texto, entre outras habilidades. (p. 16)

Dessa maneira, os conhecimentos listados estão relacionados com a aprendizagem da produção de textos, o que nos faz supor que os itens referentes a esse eixo seriam construídos de modo a levar as crianças a escreverem textos. Porém, conforme mostram as versões das provas aplicadas em 2008, os itens não exigiram esse tipo de produção e sim a escrita de palavras e frases. Vejamos as figuras que se seguem: 
Figura 1 - Item retirado do teste aplicado no primeiro semestre de 2008

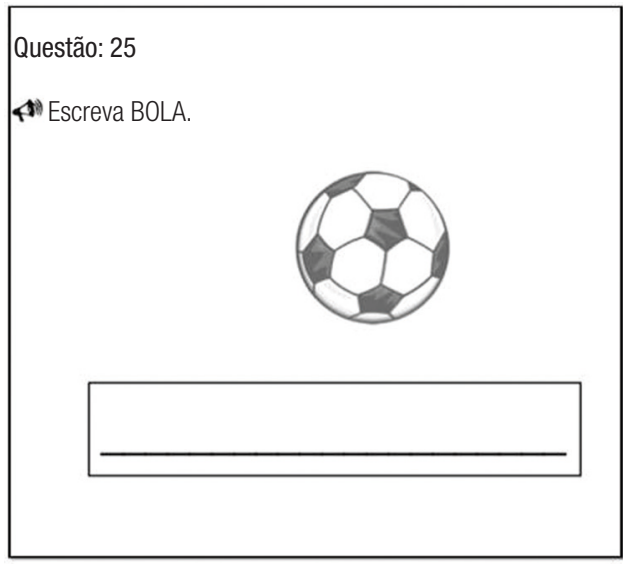

No item acima, as crianças são incentivadas a escrever uma palavra composta por sílabas simples (consoante-vogal). No item seguinte, elas são levadas a escrever uma frase.

Figura 2 - Item retirado do teste aplicado no primeiro semestre de 2008

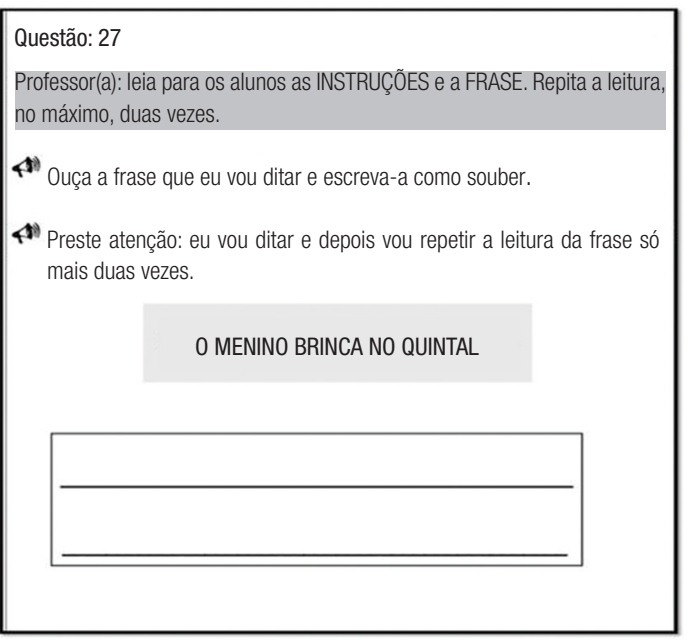

Assim, a frase é ditada três vezes pelo professor aplicador e a criança deverá escrevê-la da maneira que sabe. No Guia de interpretação e correção dos resultados (BRASIL, 2008a), são apresentadas orientações para a correção das palavras e da frase. Como ilustração, mostraremos a proposta de análise da escrita da palavra/nome bola.
Quadro 3 - Proposta de análise da palavra

\begin{tabular}{|c|c|}
\hline \multicolumn{2}{|c|}{$\begin{array}{l}\text { QUESTÃ0 } 25 \\
\text { Proposta de análise da escrita do nome: BOLA. }\end{array}$} \\
\hline A (correta) & A palavra foi grafada SEM ERROS ortográficos. \\
\hline B (correta) & $\begin{array}{l}\text { A palavra foi grafada com erro(s) ortográfico(s), ou } \\
\text { seja, com violação de regra ortográfica. }\end{array}$ \\
\hline C (correta) & $\begin{array}{l}\text { Há incorreção no traçado de alguma(s) letra(s), } \\
\text { mas é possível decifrar a palavra. Como exemplo, } \\
\text { podemos citar os casos de troca de letras que } \\
\text { representam sons muitos próximos como "b" } \\
\text { e "p", em que o aluno pode trocar "b" por "p" } \\
\text { escrevendo "pola" }\end{array}$ \\
\hline D (incorreta) & $\begin{array}{l}\text { A escrita é apresentada com omissões, } \\
\text { acréscimos ou trocas de letras em algumas } \\
\text { sílabas, de modo aproximado ou de modo } \\
\text { muito diferente da palavra. Nesse caso, há } \\
\text { um comprometimento maior na decifração da } \\
\text { palavra, sendo difícil entender o que o aluno } \\
\text { escreveu, senão se souber, de antemão, o que } \\
\text { ele intencionava escrever. Ex.: pora, pona. }\end{array}$ \\
\hline E (incorreta) & $\begin{array}{l}\text { A escrita é silábica, apresentando uma letra para } \\
\text { cada sílaba. Ex.: BL, BA, OL. }\end{array}$ \\
\hline$F$ (incorreta) & $\begin{array}{l}0 \text { registro foi apresentado por meio de desenhos, } \\
\text { garatujas ou uso de letras que não apresentam } \\
\text { relação com a escrita da palavra. EX.: AOR, IERJ }\end{array}$ \\
\hline
\end{tabular}

Fonte: Documento Guia de interpretação e correção dos resultados (BRASIL, 2008a, p. 9).

Como podemos observar, a proposta de análise leva em conta aspectos ortográficos. Por isso, as noções de correto e incorreto são utilizadas na análise ou avaliação/classificação da escrita. A proposta de correção da frase considera aspectos gramaticais relacionados com a construção de uma frase simples (composta de sujeito, verbo e predicado). Nesse sentido, podemos concluir que os itens associados ao eixo escrita contradizem a concepção de escrita expressa no documento Passo a passo (BRASIL, 2008b), e talvez esse tenha sido um dos motivos da supressão desse eixo da Matriz de Referência.

Com relação ao eixo leitura, predominantemente referente à avaliação do letramento inicial, a partir de 2009, também houve redução dos descritores, tal como demonstra o Quadro 4: 
Quadro 4 - Descritores relacionados com o eixo leitura no período de 2008 a 2011

\begin{tabular}{|c|c|c|c|c|}
\hline Eixo & 2008 & 2009 & 2010 & 2011 \\
\hline \multirow[t]{8}{*}{ Leitura } & D7: Ler palavras. & D4: Ler palavras. & D4: Ler palavras. & D4: Ler palavras. \\
\hline & $\begin{array}{l}\text { D8: Localizar informação em } \\
\text { textos. }\end{array}$ & D5: Ler frases. & D5: Ler frases. & D5: Ler frases. \\
\hline & D9: Inferir informação. & $\begin{array}{l}\text { D6: Localizar informação } \\
\text { explícita em textos. }\end{array}$ & $\begin{array}{l}\text { D6: Localizar informação } \\
\text { explícita em textos. }\end{array}$ & $\begin{array}{l}\text { D6: Localizar informação } \\
\text { explícita em textos. }\end{array}$ \\
\hline & $\begin{array}{l}\text { D10: Identificar assunto de } \\
\text { um texto lido ou ouvido. }\end{array}$ & $\begin{array}{l}\text { D7: Reconhecer assunto de } \\
\text { um texto. }\end{array}$ & $\begin{array}{l}\text { D7: Reconhecer assunto de } \\
\text { um texto. }\end{array}$ & $\begin{array}{l}\text { D7: Reconhecer assunto de } \\
\text { um texto. }\end{array}$ \\
\hline & $\begin{array}{l}\text { D11: Antecipar assunto do } \\
\text { texto com base em título, } \\
\text { subtítulo, imagens. }\end{array}$ & $\begin{array}{l}\text { D8: Identificar a finalidade } \\
\text { do texto. }\end{array}$ & $\begin{array}{l}\text { D8: Identificar a finalidade } \\
\text { do texto. }\end{array}$ & $\begin{array}{l}\text { D8: Identificar a finalidade } \\
\text { do texto. }\end{array}$ \\
\hline & $\begin{array}{l}\text { D12: Identificar a } \\
\text { finalidade do texto pelo } \\
\text { reconhecimento do } \\
\text { suporte, do gênero e das } \\
\text { características gráficas. }\end{array}$ & $\begin{array}{l}\text { D9: Estabelecer relação } \\
\text { entre partes do texto. }\end{array}$ & $\begin{array}{l}\text { D9: Estabelecer relação } \\
\text { entre partes do texto. }\end{array}$ & $\begin{array}{l}\text { D9: Estabelecer relação } \\
\text { entre partes do texto. }\end{array}$ \\
\hline & $\begin{array}{l}\text { D13: Reconhecer a ordem } \\
\text { alfabética. }\end{array}$ & D10: Inferir informação. & D10: Inferir informação. & D10: Inferir informação. \\
\hline & $\begin{array}{l}\text { D14: Estabelecer relações de } \\
\text { continuidade temática. }\end{array}$ & & & \\
\hline
\end{tabular}

De acordo com o Quadro 4, há uma gradação das unidades utilizadas na leitura: palavras, frases e pequenos textos. Por outro lado, os descritores relacionados com o eixo apropriação do sistema de escrita privilegiam a relação entre sons e letras, o reconhecimento de letras e de sílabas. As palavras são utilizadas, nos testes, apenas como contextos linguísticos que permitem a identificação dessas unidades. Assim, elas não são tratadas como unidades da comunicação discursiva, mas como unidades da língua. 0 mesmo pode ser dito com relação às frases e aos textos, pois, como será analisado, a leitura de pequenos textos não visa à construção de sentidos ou ao diálogo.

Outra mudança na Provinha Brasil, no ano de 2010, diz respeito à introdução, no documento Caderno do professor aplicador: guia de aplicação (BRASIL, 2010a), de comentário relativo a cada item da prova. A introdução do comentário visa a informar ao professor aplicador o que os itens pretendem medir e, também, o que a criança deve fazer para que a resposta seja considerada correta, conforme mostra a Figura 3:
Figura 3 - Item retirado do teste aplicado no primeiro semestre de 2010

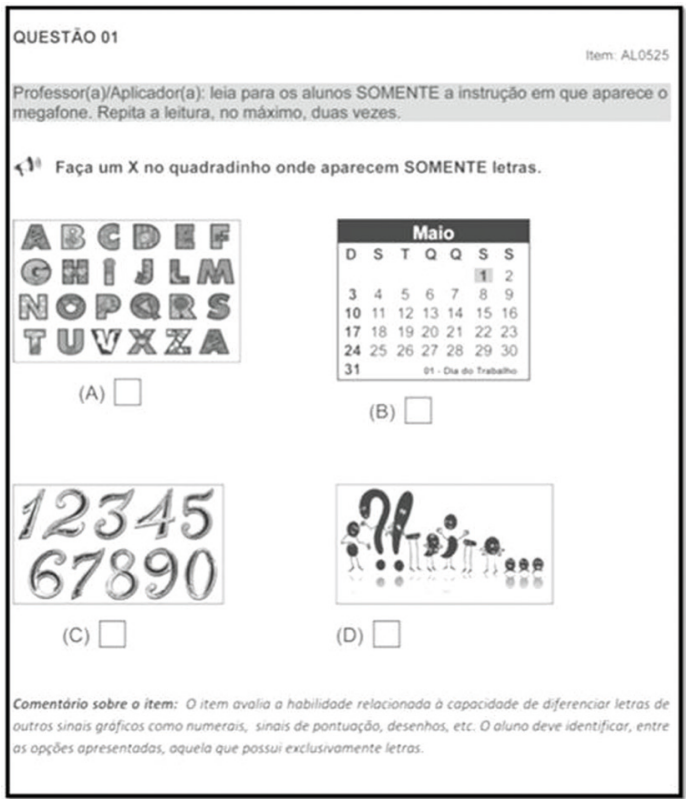

Nesse sentido, os elaboradores da prova pretendem municiar o professor aplicador de elementos que garantam a correção e interpretação correta das respostas, assegurando, ainda, o controle das correções. 
Mais uma mudança na Provinha Brasil ocorreu nos anos de 2009 e 2011 e diz respeito ao número de itens que a compõem. Em 2008, a prova era composta por 27 itens; em 2009, esse número foi reduzido para 24. De certo modo, tal redução pode ser explicada pela redução dos eixos que compunham as provas aplicadas em 2008. No ano de 2011, esse número é novamente reduzido para 20 itens. Segundo explicado no Guia de correção e interpretação dos resultados (BRASIL, 2011a), a diminuição visou a "atender as sugestões de diminuir a extensão da prova, por ser cansativa” (p. 14). É preciso destacar que essa redução na Provinha Brasil não prejudica os critérios estatísticos do instrumento, visto que permite toda a cobertura da Matriz de Referência da avaliação.

Finalmente, a última mudança, ocorrida nos anos de 2009 e 2011, refere-se ao número de documentos que compõem o kit da prova. Se, em 2009, havia sete documentos - (a) Orientações para as secretarias de educação; b) Passo a passo; c) Caderno do aluno; d) Caderno do professor aplicador I: orientações gerais; e) Caderno do professor aplicador II: guia de aplicação; f) Guia de correção e interpretação de resultados; g) Reflexões sobre a prática -, a partir de 2011 o kit passou a ser constituído apenas por quatro documentos - a) Caderno do aluno; b) Guia de aplicação; c) Guia de correção; d) Reflexões sobre a prática. De certo modo, as informações contidas nos documentos excluídos do kit estão presentes nos documentos mantidos em 2011.

\section{Concepções que sustentam o programa}

Segundo escrito no documento Passo a passo (BRASIL, 2010c), a Provinha Brasil avalia a alfabetização e o letramento inicial. Em seguida, no mesmo documento, é assinalado que, em função das características da prova (múltipla escolha) e de seus objetivos, foi necessário definir uma Matriz de Referência contendo as habilidades de leitura e escrita a serem avaliadas. Assim, as habilidades constantes na Matriz de Referência estão fundamentadas na concepção de que alfabetização e letramento são processos a serem desenvolvidos de forma complementar e paralela, entendendo-se a alfabetização como o desenvolvimento da compreensão das regras de funcionamento do sistema de escrita alfabética e o letramento como as possibilidades de usos e funções sociais da linguagem escrita, isto é, o processo de inserção e participação dos sujeitos na cultura escrita. (BRASIL, 2010c, p. 9)

Aparentemente, a proposição de complementaridade e paralelismo entre os processos de alfabetização e de letramento expressa na citação parece advir das ideias defendidas por Magda Soares (2004) quanto à indissociabilidade desses processos. Segundo ela, a alfabetização é "entendida como processo de aquisição e apropriação do sistema da escrita, alfabético e ortográfico" (p. 16), e o letramento é compreendido,

no que se refere à etapa inicial da aprendizagem da escrita, como a participação em eventos variados de leitura e de escrita, e o conseqüente desenvolvimento de habilidades de uso da leitura e da escrita nas práticas sociais que envolvem a língua escrita, e de atitudes positivas em relação a essas práticas. (p. 16, grifos nossos)

Assim, a autora distingue alfabetização e letramento, mas, ao mesmo tempo, propõe a indissociabilidade desses processos, pois a alfabetização deve ocorrer em práticas de letramento. Vale notar, ainda, que Soares (2004) entende o letramento inicial no que se refere à etapa inicial da aprendizagem da escrita, portanto, na alfabetização.

0 termo indissociabilidade por ela utilizado, de acordo com o Novo Dicionário Aurélio da Língua Portuguesa, significa "qualidade de indissociável”, isto é, diz respeito àquilo que não pode ser dissociado, que 
não pode ser dividido em partes sob o risco de perder sua natureza específica. Em termos análogos, as duas partículas de hidrogênio e a partícula de oxigênio que compõem a água, quando dissociadas ou isoladas, não produzem água, porque possuem naturezas e composições distintas. Poderíamos levantar uma série de questionamentos quanto à questão, mas nos interessa entender que, na perspectiva da autora, a indissociabilidade desses processos produz o indivíduo letrado, capaz de fazer uso da leitura e da escrita em práticas sociais e profissionais.

Por outro lado, o termo complementaridade, de acordo com o mesmo dicionário, significa: "Aspecto ou manifestação de um mesmo fenômeno que pode ser investigado ou medido separadamente, mas não simultaneamente". Por sua vez, o termo complementar, utilizado no documento Passo a passo (BRASIL, 2010c), significa: "1. Que serve de complemento. 2. Pertencente ou relativo a complemento. 3. Que sucede ao elementar". Já o termo paralelo significa: "Que marcha a par do outro ou progride na mesma proporção". Sendo assim, o termo complementar ou seu derivado complementaridade parecem efetivamente mais apropriados para explicar a relação dos dois processos que se pretende medir na Provinha Brasil: a alfabetização e o letramento inicial. A despeito da proposta de indissociabilidade, eles são medidos separadamente e se relacionam, respectiva e predominantemente, com os eixos apropriação do sistema de escrita e leitura.

Para termos uma visão geral do número de itens das provas aplicadas em 2009 e 2010 que testam as capacidades relativas aos descritores/habilidades do eixo apropriação do sistema de escrita, apresentamos o quadro que se segue ${ }^{2}$ :

Quadro 5 - Número de itens relacionados com cada uma das capacidades ligadas ao eixo apropriação do sistema de escrita

\begin{tabular}{|c|c|c|c|c|c|}
\hline Habilidades & Capacidades & $2009 / 1$ & $2009 / 2$ & $2010 / 1$ & $2010 / 2$ \\
\hline \multirow{3}{*}{ D1: Reconhecer letras. } & Diferenciar letras de outros sinais gráficos. & 1 & 1 & 1 & 1 \\
\hline & Identificar pelo nome as letras do alfabeto. & 1 & 3 & 2 & 2 \\
\hline & Reconhecer os diferentes tipos de grafia das letras. & 1 & 1 & 1 & 2 \\
\hline \multirow[b]{2}{*}{ D2: Reconhecer sílabas. } & Identificar número de sílabas que formam uma palavra por contagem. & 1 & & 1 & \\
\hline & $\begin{array}{l}\text { Identificar número de sílabas que formam uma palavra por } \\
\text { comparação das sílabas de palavras dadas por imagens. }\end{array}$ & & 1 & & 1 \\
\hline \multirow{4}{*}{$\begin{array}{l}\text { D3: Estabelecer relação } \\
\text { entre unidades sonoras } \\
\text { e suas representações } \\
\text { gráficas. }\end{array}$} & Identificar em palavras a representação de vogais nasalizadas. & & 1 & 1 & \\
\hline & Identificar em palavras letras que possuem correspondência única. & & & 1 & 1 \\
\hline & $\begin{array}{l}\text { Identificar em palavras letras com mais de uma correspondência } \\
\text { sonora. }\end{array}$ & 1 & & & \\
\hline & Identificar sílabas. & 2 & 3 & 2 & 4 \\
\hline Total & & 7 & 10 & 9 & 11 \\
\hline
\end{tabular}

Fonte: Dados da pesquisa.

Conforme mostra o Quadro 5, o maior número de itens visa a verificar se as crianças identificam os nomes de letras e sílabas, o que evidencia que o conhecimento dessas unidades é a base do processo de alfabetização. Assim, os itens relacionados com o reconhecimento de sílabas, por exemplo, testam a consciência silábica. Vejamos o seguinte exemplo:

2- Para a construção dos quadros 5 e 6 , utilizamos as versões das provas aplicadas em 2009 e 2010, porque, para a elaboração dos testes, foram mantidos os mesmos eixos, habilidades/descritores, capacidades e também 0 mesmo número de itens na prova.
Figura 4 - Item retirado do teste aplicado no segundo semestre de 2010

40. Faça um $x$ no quadradinho da palavra que começa com o som de $\angle D A>$
como em DATA.
(A) $\square$ BALÉ
(B) $\square$ CADEIRA
(C) $\square$ DADO
(D) $\square$ PANELA


Esse item mede a habilidade de a criança relacionar sílaba e sinais gráficos que a representam. Assim, o aplicador pronuncia a sílaba isoladamente e indica sua presença em uma palavra para que as crianças a identifiquem em um termo escrito. Nesse caso, a habilidade requerida é de reconhecimento de sinais gráficos que representam uma dada sílaba em uma palavra. Para que a criança a reconheça, será necessário que tenha memorizado a grafia da sílaba. Há itens que cobram o reconhecimento de sílabas no meio e no final das palavras. Além desse tipo de habilidade, os itens cobram o reconhecimento da grafia dos fonemas. Vejamos outro exemplo:

Figura 5 - Item retirado do teste aplicado no primeiro semestre de 2010

4il Faça um $X$ no quadradinho da primeira letra da palavra TUCANO

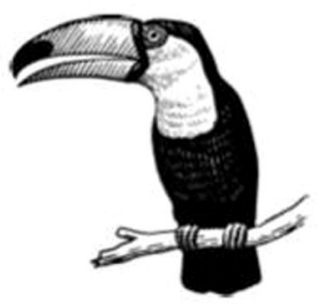

(A)

(B)

(C) $\square P$

(D) $\square \mathrm{T}$
No item da Figura 5, as crianças têm de reconhecer a grafia do som [t] da palavra $t u$ cano, que tem correspondência univoca. Esses dois exemplos demonstram que o teste reforça o ensino das letras, das sílabas, de relações entre sons e letras e de palavras. A avaliação dessas habilidades segue uma gradação psicológica, ou seja, os níveis de desenvolvimento da escrita previamente estabelecidos (fase silábica, fase silábico-alfabética e alfabética).

Como aventado, a análise dos itens da prova evidencia que a palavra é vista como contexto linguístico que permite a identificação de unidades da língua menores do que ela. Essas unidades são organizadas e seguem uma ordem crescente de dificuldades, baseada na diminuição da motivação fonética. Porém, a definição desse tipo de gradação do ensino das relações entre sons e letras para todo o território nacional é complicada, porque desconsidera que o modo como os sons são articulados e produzidos varia de acordo com as regiões e, também, conforme grupo social, classe social etc. Por exemplo, as letras t e d não representam apenas os sons /t/ e /d/. Em algumas regiões brasileiras, elas expressam também os sons $/ \mathrm{t} / \mathrm{d}$ e /d / e, por isso, nessas regiões, não possuem correspondência sonora única.

Considerando a quantidade de itens relativos ao eixo apropriação do sistema de escrita, 
podemos dizer, grosso modo, que a Provinha Brasil tem avaliado, em maior proporção, a leitura ou o letramento inicial. No primeiro semestre de 2009, observamos que 29,16\% dos itens referiam-se à apropriação do sistema de escrita; no segundo semestre daquele mesmo ano, eram 42,88\%; no primeiro e no segundo semestre de 2010, 37,50\% e 45,83\%, respectivamente, avaliaram esse eixo.

Considerando os descritores relacionados com o eixo leitura e as versões das provas aplicadas nos anos de 2009 e 2010, o quadro que se segue mostra o número de itens do teste referentes a cada descritor.

Quadro 6 - Descritores/habilidades ligados ao eixo leitura e número de itens relacionados nas provas aplicadas no período de 2009 a 2010

\begin{tabular}{|c|c|c|c|c|}
\hline Habilidades & $2009 / 1$ & $2009 / 2$ & $2010 / 1$ & $2010 / 2$ \\
\hline D4: Ler palavras. & 7 & 4 & 5 & 4 \\
\hline D5: Ler frases. & 1 & 1 & 2 & 2 \\
\hline D6: Localizar informação explícita em textos. & 4 & 4 & 3 & 2 \\
\hline D7: Reconhecer assunto de um texto. & 2 & 2 & 2 & 2 \\
\hline D8: Identificar a finalidade do texto. & 2 & 2 & 2 & 2 \\
\hline D9: Estabelecer relação entre partes do texto. & - & - & - & - \\
\hline D10: Inferir informação. & 1 & 1 & 1 & 1 \\
\hline Total & 17 & 14 & 15 & 13 \\
\hline
\end{tabular}

Fonte: Dados da pesquisa.

Como mencionado, o documento intitulado Caderno do professor aplicador II: guia de aplicação (BRASIL, 2010b), além de conter orientações para a aplicação de cada item, apresenta informações sobre as habilidades avaliadas em cada um deles. Nas provas anteriores, essa informação não constava nesse documento. Não há, também, nas versões analisadas, itens que avaliem o D9 (estabelecer relação entre partes do texto). Conforme consta no documento denominado Passo a passo (BRASIL, 2010c), a não presença de itens que avaliam esse descritor tem razões técnicas. Pelos mesmos motivos, o eixo escrita foi retirado das versões dos testes analisados.

0 Quadro 4 mostra que as habilidades avaliadas envolvem a leitura de palavras e de frases, a capacidade de localização de informação explícita em textos curtos, o re- conhecimento do assunto do texto, a identificação das finalidades do texto e, finalmente, a capacidade de inferir informações. Os itens dos testes analisados que avaliam essas habilidades são muito semelhantes nas diferentes versões dos testes aplicados em 2009 e 2010.

Os itens que avaliam a leitura de palavras são mais frequentes no primeiro teste aplicado no primeiro semestre de 2009. Verificamos a presença de nove itens com essa finalidade num total de 24 , o que equivale a $37,50 \%$ do total das questões. No segundo semestre de 2009, esse número diminuiu para quatro questões $(16,67 \%$ do total de questões). No primeiro semestre de 2010, o número foi mantido e, no segundo semestre desse ano, caiu para cinco $(20,83 \%$ do total). Para exemplificar como é avaliada a leitura de palavras, apresentamos o item que se segue: 
Figura 6 - Item retirado do teste aplicado no primeiro semestre de 2009

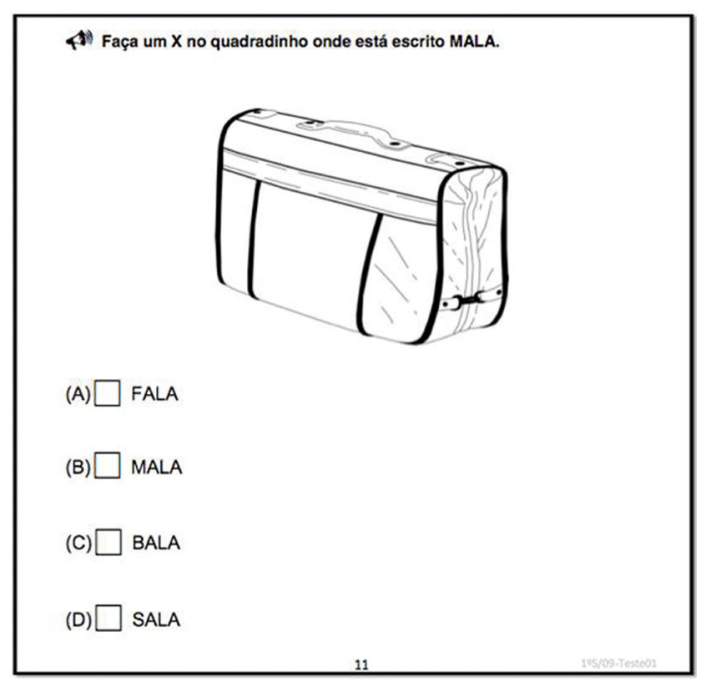

Todos os itens que avaliam a leitura de palavras são organizados praticamente da mesma forma, exceto quando a palavra é pronunciada pelo aplicador e, por isso mesmo, não se faz uso de imagens, como nos exemplos apresentados. As palavras ou os nomes que devem ser identificados pelas crianças encontram-se dentre um conjunto de quatro alternativas apresentadas. No teste aplicado no primeiro semestre de 2009, as palavras utilizadas foram mala, rato, bicicleta, panela, formiguinha, cachorro, lata, que correspondem a uma mesma classe gramatical (substantivos); apenas um substantivo está flexionado no grau diminutivo. No segundo semestre desse ano, foram utilizadas as palavras camiseta, patinho, bruxa, quiabo, sendo que a escolha seguiu o mesmo critério do teste do primeiro semestre de 2009. No primeiro semestre de 2010, as palavras foram mão, escova, vela, charrete; no segundo semestre desse mesmo ano, foram barata, natureza, ditado, caranguejo. Outro aspecto observado é a variação dos padrões silábicos: as sílabas que compõem as palavras são formadas com CV, CCV, CVC, CVV. Esses padrões são mantidos em todos os testes analisados.

A leitura de frases é avaliada em um item nos testes aplicados no ano de 2009; nos testes de 2010, tal número aumentou para dois. Desse modo, se somarmos, no último teste analisado (segundo semestre de 2010), o número de itens que avalia a habilidade de ler palavras (4) e de ler frases (2), observamos que 25\% do total dos itens são destinados à avaliação dessas duas habilidades. As frases usadas nas provas foram: Marina pega a boneca para Camila (primeiro semestre de 2009); Eu sei escrever meu nome (segundo semestre de 2009); O macaco é muito levado; 0 menino joga o papel no lixo (primeiro semestre de 2010); Tive um sonho engraçado; $A$ médica atende à criança. Como se pode verificar, a estrutura das frases é simples, composta de sujeito, verbo e predicado. Para a identificação, há casos em que o professor aplicador lê a frase ou apresenta uma imagem, conforme pode ser visto a seguir:

Figura 7 - Item retirado do teste aplicado no primeiro semestre de 2010

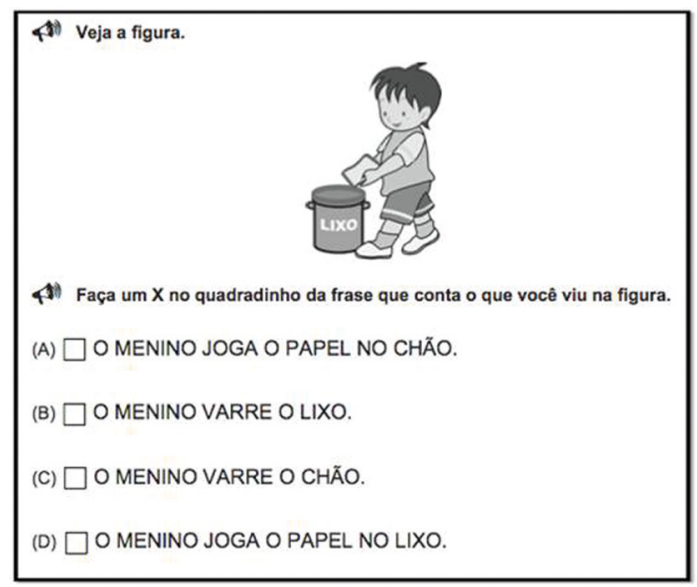

0 que a criança poderá ler/ver na figura? Uma menina ou um menino? Uma lata de lixo ou outra lata qualquer? Uma criança levando uma carta ou um bilhete? Muitas são as possibilidades de leitura que, certamente, dialogam com o contexto sociocultural do qual a criança é integrante, mas nenhuma dessas respostas pode ser encontrada nas alternativas apresentadas. Além disso, é possível que muitas crianças tenham visto colegas e adultos próximos a uma lata de lixo, mas jogando papel no chão. 0 fato 
de estar diante da lixeira não significa que esse é sempre o lugar escolhido para colocar o lixo. Se a criança assinalar essa alternativa, também não respondeu corretamente ao item.

Conforme assinala Mikhail Bakhtin (2003), uma palavra ou uma oração pode constituir-se em enunciado, sendo este definido pelo autor como a "real unidade da comunicação discursiva” (p. 274, grifos do autor). Para isso, no entanto, é necessário que faça parte de uma corrente discursiva mais ampla. Nesse sentido, o enunciado não é defınido pela sua extensão, mas seus limites são delimitados pelo fato de proporcionar a alternância de vozes, ou seja, a alternância dos falantes. Sendo assim:

0 falante termina seu enunciado para passar a palavra ao outro ou dar lugar à sua compreensão ativa e responsiva. 0 enunciado não é uma unidade convencional, mas uma unidade real, precisamente delimitada pela alternância dos sujeitos do discurso, a qual termina com a transmissão da palavra ao outro. (p. 275)

A despeito dessa característica essencial dos enunciados, as palavras e as frases são tratadas na Provinha Brasil apenas como unidades da língua. No caso da palavra, essa unidade pode ser decomposta em sílabas, as quais, por sua vez, podem ser decompostas em fonemas.

Nos testes analisados, foram quatro os itens que avaliaram a capacidade de localizar informações explícitas, no primeiro e no segundo semestre de 2009. Nos dois semestres de 2010, há três questões que avaliam essa capacidade. De modo geral, as questões são compostas da seguinte maneira: em primeiro lugar, solicita-se a leitura silenciosa de um texto curto; depois da leitura, a criança deve responder a uma pergunta; ainda, pede-se a ela que não leia em voz alta e não mostre a resposta ao colega. Vejamos o exemplo a seguir:
Figura 8 - Item retirado do teste aplicado no segundo semestre de 2010

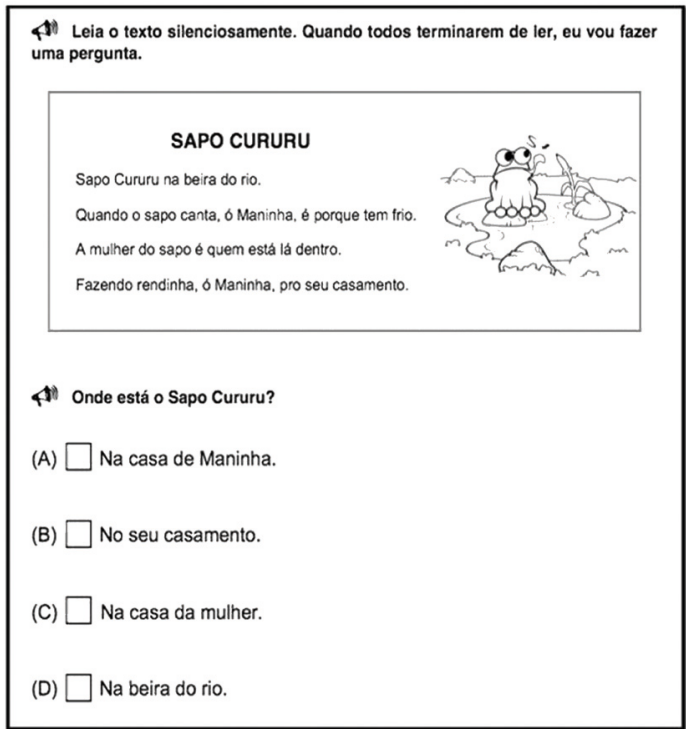

A busca de informações explícitas no texto compreende uma estratégia de leitura que não envolve a produção de sentidos. Questões desse tipo remetem à ideia de que a língua é um código que propicia a transmissão de informações a um receptor/conhecedor desse código, e de que o texto é algo a ser decodificado pelo recebedor da mensagem. Portanto, a leitura é entendida como "uma atividade que exige do leitor o foco no texto, em sua linearidade" (KOCH; ELIAS, 2006, p. 10). No item da Figura 8, por exemplo, a imagem contradiz a informação contida no texto, pois, ao que parece, o sapo está no rio e não na beira do rio. Porém, não importa a contradição entre os elementos visuais e verbais, porque o que se pretende é que a criança leve em consideração o texto em sua linearidade.

0 reconhecimento do assunto do texto foi avaliado por dois itens em cada um dos testes analisados. De modo geral, os itens são organizados obedecendo à seguinte sequência de tarefas: o professor aplicador solicita a leitura silenciosa do texto, advertindo que, após a leitura, será indicada uma nova tarefa; em seguida à leitura, ele pergunta qual é o 
assunto do texto. A resposta deve ser escolhida dentre quatro alternativas apresentadas. Vejamos um exemplo:

Figura 9 - Item retirado do teste aplicado no primeiro semestre de 2010

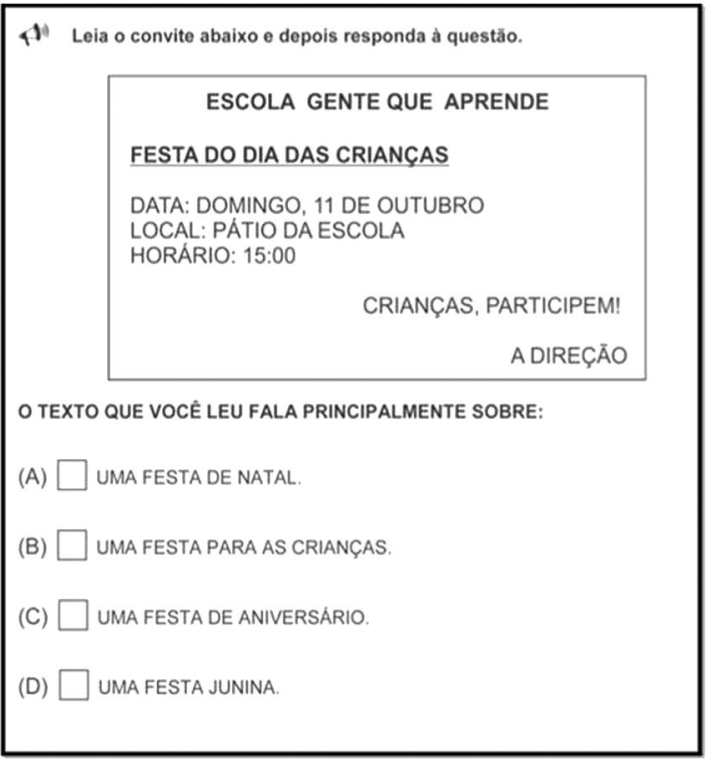

A concepção de língua/linguagem, texto e leitura que subjaz à capacidade de buscar informações explícitas no texto não difere da capacidade de reconhecer o assunto do texto. Entretanto, é importante acrescentar que as pessoas que não sabem ler, ao ouvirem um texto, sabem distinguir, dentre os vários assuntos que ele pode abordar, o assunto que lhe interessa, considerando suas necessidades e sua realidade sociocultural. Contudo, tendo em vista os objetivos da Provinha Brasil e as dificuldades técnicas para a correção de itens que levem tais aspectos em conta, as perguntas formuladas induzem, após a decodificação do texto, a uma única resposta.

A habilidade de identificar as finalidades do texto foi avaliada por dois itens em cada um dos testes analisados. A organização do item segue o mesmo padrão utilizado na construção dos itens que tiveram por objetivo avaliar a capacidade de reconhecer o assunto.
Figura 10 - Item retirado do teste aplicado no segundo semestre de 2009

4) Leia o texto silenciosamente. Quando todos terminarem de ler, eu vou dizer o que é para fazer.

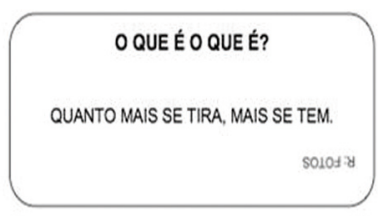

4II) Faça um $X$ no quadradinho que mostra para que esse texto serve.

(A) $\square$ FAZER UMA BRINCADEIRA.

(B) $\square$ DAR UMA NOTICIA.

(C) $\square$ ENSINAR UMA RECEITA.

(D) $\square$ VENDER UM PRODUTO.

Finalmente, a capacidade de inferir informações foi avaliada por um item em cada edição dos testes, sendo sua organização feita praticamente da mesma maneira.

Figura 11 - Item retirado do teste aplicado no primeiro semestre de 2009 .

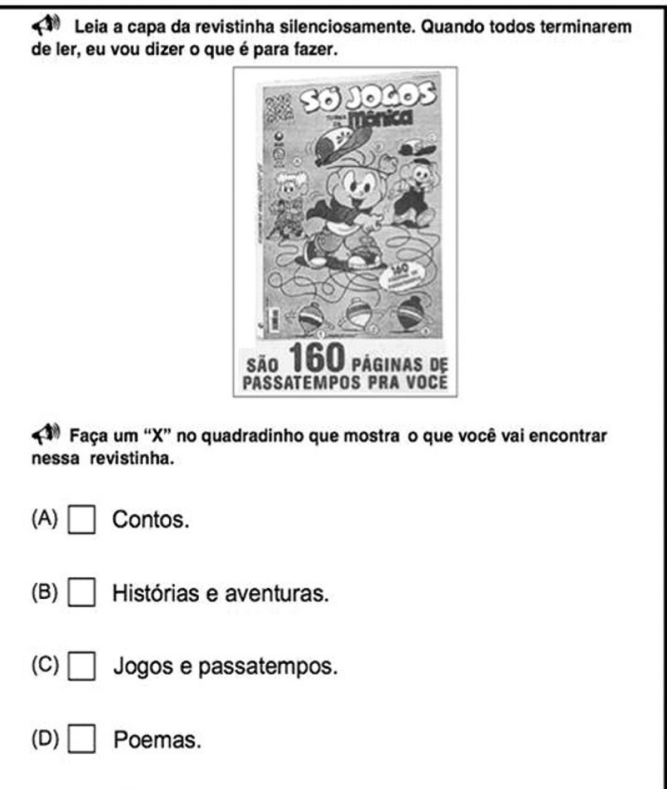


Em comparação ao número de itens relativos às capacidades de buscar informações explícitas e reconhecer o assunto e as finalidades do texto, verificamos que a quantidade de itens dedicados à capacidade de fazer inferência é bem menor em cada uma das edições analisadas da Provinha Brasil (apenas um item nas edições aplicadas nos anos de 2009 e 2010). Fazer inferência exige que o leitor mobilize conhecimentos elaborados previamente para completar aspectos não explícitos no texto, ou que estão explícitos, mas podem ser completados a partir de outros pontos de vista ou opiniões. Porém, se observarmos o item da Figura 11, concluiremos que, para fazer a suposta inferência, é necessário que a criança saiba apenas decodificar o que está escrito na capa da revista, pois a pergunta não requer a mobilização de conhecimentos prévios.

Considerando ainda o modo como o professor aplicador conduz a leitura dos textos, podemos dizer que as crianças leem para responder a questões relativas ao texto. Comentários a serem feitos pelo professor aplicador indicam essa finalidade: "Leiam silenciosamente. Quando todos terminarem, eu vou dizer o que é para fazer" (BRASIL, 2010a, p. 28). Como vimos, o que as crianças fazem após a leitura é localizar informações, reconhecer o assunto do texto, identificar para que ele serve e inferir informações. Assim, tendo em vista essas capacidades, podemos concluir que a Provinha contribui para que as crianças sejam preparadas, no início da alfabetização, em grande medida, para perceber o texto como objeto que deve ser decifrado por um receptor passivo (criança), porque as tarefas que envolvem a leitura exigem apenas o conhecimento do código escrito.

Nessa perspectiva, a leitura define-se como capacidade de reconhecimento, identificação e localização do que foi dito, portanto, como mera reprodução, e o texto como enunciação monológica. Bakhtin (1992) afırma que as enunciações monológicas não são responsivas, ou seja, elas não são respostas a nada nem a ninguém. Por isso mesmo, as tarefas relacionadas com o texto não produzem respostas, posicionamentos das crianças em relação ao escrito. Há uma única resposta em detrimento da pluralidade de sentidos dos textos e a despeito da diversidade de leitores/sujeitos.

\section{Considerações finais}

As análises da Provinha Brasil apontam para um modelo de alfabetização concebido como um conjunto de competências autônomas. Essas competências estão listadas na Matriz de Referência sob a forma de descritores, habilidades e capacidades no eixo apropriação do sistema de escrita. Se a introdução do letramento inicial visava a dar conta da dimensão pragmática, funcional, de uso da linguagem escrita de modo a garantir a participação e a inserção das crianças na cultura escrita, podemos dizer que as capacidades elencadas na Matriz referentes à leitura e os itens da Provinha relacionados não contribuem para isso.

A partir das análises construídas nos tópicos anteriores, podemos, então, concluir que a concepção de língua/linguagem como estrutura sustenta a Matriz de Referência e a construção dos itens que compõem a Provinha Brasil. Nessa perspectiva, conforme assinala Bakhtin (1992),

o centro organizador de todos os fatos linguísticos [...] situa-se [...] no sistema linguistico, a saber as formas fonéticas, gramaticais e lexicais da língua. (p. 77, grifos do autor)

Esse sistema, constituído por leis próprias e independentes dos sujeitos, requer do aprendiz assimilação passiva, porque, conforme aponta o mesmo autor: "Um tal sistema tem que tomá-lo e assimilá-lo no seu conjunto, tal como ele é" (p. 78), com formas fonéticas, gramaticais e lexicais. No processo de assimilação,

não há lugar [..] para quaisquer distinções ideológicas, de caráter apreciativo: é pior 
ou melhor, belo ou repugnante etc. $\mathrm{Na}$ verdade, só existe um critério linguístico: está certo, está errado. (p. 78)

Coerente com essa concepção de língua/linguagem, cada item da prova implica uma única resposta correta, mesmo quando se trata de leitura.

A criança que é submetida ao teste faz um trabalho de identificação das unidades fonéticas em palavras e de reconhecimento das formas lexicais (palavras) e gramaticais (decodificação de frases e pequenos textos). Desse modo, ela age sobre sua língua de uso cotidiano como se ela fosse uma língua morta. Segundo Bakhtin (1992), as formas do sistema linguístico constituíram-se em função de "duas tarefas fundamentais da linguística: uma heurística e a outra pedagógica" (p. 99, grifos do autor).

Nessa perspectiva, ensinar a ler é ensinar a decodificar para que os aprendizes possam reconhecer e reproduzir os sentidos expressos no texto pelo autor. Obviamente, tal concepção distancia-se da leitura como processo de construção de sentidos e, por conseguinte, como processo de compreensão ativa e responsiva. As capacidades e habilidades avaliadas na Provinha Brasil, infelizmente, buscam o silenciamento das contrapalavras dos leitores, vistos como receptores passivos de informações. Entretanto, conforme sublinha Bakhtin (1992), uma tal visão do ouvinte ou do leitor é uma abstração, assim como considerar o texto como uma enunciação monológica, que não responde a nada e nem funda outros e novos dizeres, também o é.

Resumindo, podemos dizer que, na perspectiva dos especialistas do MEC responsáveis pela elaboração da Provinha Brasil, a língua/linguagem é um sistema pronto e acabado; a leitura é concebida como decodificação; o texto, como enunciação monológica. Sendo assim, é importante questionar: de que modo a Provinha, pensada como instrumento pedagógico e, portanto, educativo, poderá contribuir para a formação de leitores e escritores? Infelizmente, se permanecer dessa forma, ela certamente só poderá contribuir para a formação de massas silenciosas e adaptadas à realidade socioeconômica. 


\section{Referências}

BAKHTIN, Mikhail. Marxismo e filosofia da linguagem. São Paulo: Hucitec, 1992.

. Estética da criação verbal. São Paulo: Martins Fontes, 2003.

BRASIL. Congresso Nacional. Câmara dos Deputados. Comissão de Educação e Cultura. Grupo de trabalho alfabetização infantil: os novos caminhos - relatório final. 2. ed. Brasília: Câmara dos Deputados, Coordenação de Publicações, 2007.

Ministério da Educação. Portaria Normativa n 10, de 26 de abril de 2007. Disponível em: <http://provinhabrasil.inep. gov.br/legislacao>. Acesso em: 30 maio 2012.

Inep, Ministério da Educação. Provinha Brasil: guia de correção e interpretação de resultados. Brasília: Inep e Ministério da Educação, 2008a.

. Inep, Ministério da Educação. Provinha Brasil: passo a passo (primeiro semestre). Brasília: Inep e Ministério da Educação, 2008b.

. Inep, Ministério da Educação. Provinha Brasil: passo a passo. Brasília: Inep e Ministério da Educação, 2009.

. Inep, Ministério da Educação. Provinha Brasil: caderno do professor aplicador I - guia de aplicação (segundo semestre). Brasília: Inep e Ministério da Educação, 2010a.

Inep, Ministério da Educação. Provinha Brasil: caderno do professor aplicador II - guia de aplicação (primeiro semestre). Brasília: Inep e Ministério da Educação, 2010b.

. Inep, Ministério da Educação. Provinha Brasil: passo a passo. Brasília: Inep e Ministério da Educação, 2010c.

Inep, Ministério da Educação. Provinha Brasil: guia de correção e interpretação dos resultados (primeiro semestre). Brasília: Inep e Ministério da Educação, 2011a.

. Inep, Ministério da Educação. Provinha Brasil: reflexões sobre a prática (segundo semestre). Brasília: Inep e Ministério da Educação, 2011b.

CARVALHO, Gisele Francisca da Silva; MACEDO, Maria do Socorro Alencar Nunes. Avaliação oficial: o que dizem os mediadores da política pública sobre o impacto na prática docente. Revista Estudos em Avaliação Educacional, São Paulo, v. 21, n. 46, p. 253-270, maio/ago. 2010. Disponível em: <http://www.fcc.org.br/institucional/2011/01/17/1659/>. Acesso em: 25 fev. 2012.

DANTAS, Lays Maria Vinhaes. As contribuições das políticas de avaliação educacional em larga escala: 0 caso da avaliação da aprendizagem na Bahia. 2009. Tese (Doutorado em Educação) - Núcleo de Pós-Graduação em Educação, Universidade Federal da Bahia, Salvador, 2009

FERREIRA, Aurélio Buarque de Holanda. Novo dicionário da língua portuguesa. 2. ed. Rio de Janeiro: Editora Nova Fronteira, 1986.

ESTEBAN, Maria Teresa. Provinha Brasil: desempenho escolar e discursos normativos sobre a infância. Sísifo: Revista de Ciências da Educação, n. 9, p. 47-56, 2009. Disponível em: <http//sisifo.fpce.ul.pt.>. Acesso em: 25 fev. 2012.

KOCH, Igedore Villaça; ELIAS, Vanda Maria. Ler e compreender os sentidos do texto. 2. ed. São Paulo: Contexto, 2006.

MARQUES, Cláudio de Albuquerque; AGUIAR, Rui Rodrigues; CAMPOS, Márcia Oliveira Cavalcante. Programa alfabetização na idade certa: concepções, primeiros resultados e perspectivas. Revista Estudos em Avaliação Educacional, São Paulo, v. 20, n. 43, p. 275-291, maio/ago. 2009. Disponível em: <http://www.fcc.org.br/institucional/2011/01/17/1659/>. Acesso em: 25 fev. 2012. 
OLIVEIRA, João Batista Araújo e. Avaliação em alfabetização. Ensaio: Avaliação e Políticas Públicas Educacionais, Rio de Janeiro, v. 13, n. 48, p. 375-382, jul./set. 2005.

ROCHA, Gladys; MARTINS, Raquel Fontes. Meta-avaliação da alfabetização: constituição de um corpus de escrita infantil e suas contribuições para a avaliação da alfabetização, leitura e escrita. In: REUNIÃO ANUAL DA ASSOCIAÇÃO NACIONAL DE PÓSGRADUAÇÃO E PESQUISA EM EDUCAÇÃO, 30., 2010, Caxambu. Anais eletrônicos. Disponível em: <http://www.anped.org. br/33encontro/app/webroot/files/file/Trabalhos\%20em\%20PDF/GT10-6620--Int.pdf>. Acesso em: 25 fev. 2012.

SOARES, Magda Becker. Letramento e alfabetização: as muitas facetas. Revista Brasileira de Educação, São Paulo, n. 25, p. 5-17, 2004.

Recebido em: 01/04/2012

Aprovado em: 28/05/2012

Cláudia Maria Mendes Gontijo é doutora em Educação pela Universidade Estadual de Campinas. Atualmente, é professora do Departamento de Linguagens, Cultura e Educação, do Centro de Educação da Universidade Federal do Espírito Santo, e integrante da linha de pesquisa em Educação e Linguagens do Programa de Pós-Graduação em Educação da mesma universidade. 